\title{
5 in prose
}

by W. S. Merwin

\section{What Happened While They Were Away}

The ........s (they were quite real, they are quite real, they were wellknown in that section of .........., which is the name of the town, they were even what is known as respected, even very respected, and if I do not give their name it is not because I do not know it but because on the contrary they are terribly real, and they might be hurt. More important, they might sue me.)

The $s$ were supposed to be away for the summer. I say they were supposed to be away for the summer. And they were away for the summer, but someone had been left behind. He thought there never had been such an empty afternoon. There was not a flower in the parched garden. They had all been put away. There were no passers-by to greet, naturally, because everybody had heard that the s were away. In the vacant lot next door the dust had its own games, but he did not know anybody there. Everybody seemed to have changed. And the whole summer stretched ahead. Meanwhile the present was empty all the way up to the sky. And then he noticed that something seemed to have happened to everything he could remember. It was no longer solid. He did not dare watch. Bitterly he turned his eyes away.

Those with stronger characters may disapprove. He felt he had no choice. He made his way down into the cellar. Mr. .......... always said "Are you sure you've locked the cellar door?" but he made his way down for all that. Oh the summer light through the cobwebs on the cellar windows, resting fondly on the faded labels of the endless cans of peas bought wholesale, years before, at a discount, and on the equally faded labels of numerous larger cans of sauerkraut, bought in bulk, years before, from an acquaintance, and on the labels, faded only at the ends of the boxes, of soap flakes, bought in quantity, years before, at a saving, from an advertisement, and on the yellowing labels of dark red jars containing homemade jams-their ink now turned the color of iodine, and their labels like turned-up eyes of people lying on their sides trying to remember. So! The cupboard doors were open. This was what happened when the ......... backs were turned! Nothing seemed to be missing (though how could he tell?) but there were signs. A person had been there. Perhaps was still there! Yes, he could see: it was an old woman. There were her overshoes. She kept them out here. There was her umbrella. Old woman's umbrella. He was on the scent now. He listened, which of course he would have done well to do in the first place. From the inner room, the boiler room, he distinctly heard sounds coming-sounds repeated over and over, like the faint rasping of a broom on a hollow paving stone, but quicker. Like a broom in sand, but quicker. More like a quiet hooting, 
like someone breathing all the time through a tube. Of course he went in. But he went in slowly. So that his eyes would be able to set themselves down in the darkness in there without mishap.

But it was not as dark in there as he had expected it to be. It was the boiler and the coal bins that gave the impression that it would be dark. Beyond them the light was quite good considering that no one was at home. And there-he had been absolutely right-was the foot of an old woman's bed, with the shape of an old woman's feet under the old quilt. Sitting bolt upright in the bed, with her shawl around her shoulders, was a skeleton, and sitting on two bentwood chairs beside the bed, very close to her, with their backs to him, were two skinny men, shaking and making the sound that he had heard. He stood there, and they went on making the same sound. He could not tell whether they were laughing or crying. He edged around toward the light to get a better look, to see whether he could see any tears. (He remembered that that was always the first thing to do.) When he got to where he could see their faces, which were very skinny indeed, he still could not see any tears. On the other hand he still was not sure whether they were laughing or crying. They never looked up, never seemed to notice him. They were gazing the whole time at the skeleton's face. It was awkward. With the ...........s away. He was not quite sure what to do next. He was not sure how far his responsibility could be said to extend. He cleared his throat. Still the two skinny men paid no attention to him, sitting there with their hands on the edge of the bed, leaning forward to look into the skeleton's face. Well, in the end he went right up to one of them and said, "Excuse me," and started to feel his pulse (which he had finally remembered is always the next thing to do).

It was only then that the skinny man turned to look at him. The other went right on watching the skeleton.

"Excuse me," said someone, "but I only wanted to see if you were all right." The skinny man just stared at him.

"The ..........s are away, you know," someone said. Still no answer. The same blank stare. The other skinny man still paying no attention, and both of them still shaking and making that sound.

Then the one whose pulse was being felt stopped making the sound. $\mathrm{He}$ looked at someone. "It's too late," he said.

"Yes," someone agreed. The skinny man's pulse seemed weak and rapid.

"The ...........s are away," the skinny man told him in a dazed voice. What he said came from a long way off. He went on. "So we made our way down here." There were signs that another person-yes, it was an old woman-had come down ahead of them. Appeared to have moved right in. They had seen her overshoes. Old woman's overshoes. And her umbrella. Old woman's umbrella. Though it had not been raining for weeks. Then they had heard a sound in the boiler room, like a sighing. So of course they had gone in. It was not as dark as they would have expected. And there she was, a very old woman lying in the bed. She had asked them what they wanted and they had told her that the ........s were away and that they had made their way down here. She had said that she knew that the ..........s were away. Well, they had told her, they would go now and not disturb her. But then she had asked them not to go, please. 
Please not to go. So they had stood looking at her.

Then she had asked them whether they could see all right and they had told her that they could see fine, thank you. So she had told them to bring their chairs over by the bed. They didn't have any chairs but they had found two and brought them over to the bed and sat down beside her. Then she asked them again whether the light was all right and they said it was fine. And as soon as they said that she had sat bolt upright in bed, looking past them, and out of her eyes everything that she had ever seen had begun to flow in two almost identical films that ran down her face and over the bed and onto the floor and out the door, while they sat and watched and it became clearer and clearer.

\section{The Islands}

The islands always disappeared.

After a long time men learned to build their own islands. Then men too began to disappear. There were more and more men all the time and the faster there were more of them the faster they disappeared.

Under the sea there lived an old man bent over like a bell, who could hear pain. He could hear the pain even of those who disappeared. He could hear the pain of disappearance itself, of which night is one form and day another. $\mathrm{He}$ could hear the pain which those who disappear left behind. There was nothing he could do. All suffering flowed into the sea and the weight of the sea rocked on his eardrum. His breathing made the waves. When he saw the moon he was reminded at once of how everything was and he sighed, and the tide turned once more. The worst thing was that he could not tell whether the pain he heard was from the past, the present or the future, for pain was already time's keeper.

It is because I forget, he said. If I did not forget things they would not disappear. He tried to remember. The pain grew worse. And everything, as it disappeared in the sea after all his efforts, was still crushed into one terrible syllable that sank straight toward him. It is because I know too much, he said. And he tried to forget. But the whole sea shook him to remind him, bringing the echoes.

If there is no hope for me perhaps I can help someone else, the old man said, for he was a good old man. For his own sake and for theirs he tried to find someone who knew nothing about pain. At last he gathered around himself the unborn and in a very low voice began to tell them stories about the islands.

\section{A Thing of Beauty}

Sometimes where you get it they wrap it up in a clock and you take it home with you and since you want to see it it takes you the rest of your life to unwrap it trying harder and harder to be quick which only makes the bells ring more often. 


\section{Noon}

He who is wearing the helmet of Death is walking at the foot of the walls. The shadow of the enormous casque falls over his body like a bell. He lets others do his shouting for him. No one shouts, wearing the helmet of Death. He turns. He waits.

Around him the empty plain, and the dead, who have taken the form of doors, each standing by itself, locked, with no shadow. Large birds alight, bringing their own shadows to walk on, and disappear behind the doors. He is wearing the helmet of Death.

While he wears it no weapon can touch him, no sound can startle him, no sight can move him.

No one dares fight with him. The silence is his triumph.

But Death has missed the helmet.

\section{The Dark Sower}

Now although we say it is spring the days of glass are assembling. Mogog the Dark Sower walks the earth once more. For him it is the time of year-but for him a year is a lapse that we have not learned to describe, since for us it has come only once. Is it three thousand, or ten thousand, or fifty thousand, or a hundred thousand years? Between sowings, as the centuries pass without his reappearance, his figure and his office are mistaken. He becomes confused with lesser and more sociable deities. $\mathrm{He}$ is portrayed as the gray god who mildews the grain, hence as the lord of ailment. He occurs on their altars with a face of smoke and they pray to him not to be consumed. He becomes the god of ice (more accurately) and they imagine that it is the ice they know, and they offer him fish and birds to seize and hold in his heart. They think of it as a heart. But what they know of cold is no more than the shadow of a gatehouse in his dominion. And now he has come again.

He walks at his time across the blue sky of the earth and he sows the days of glass. They do not fall immediately. They fly out from his hand like birds settling at evening, but transparent. With a tiny clinking like that of sleet they congregate at a height known beforehand, which they remember from the last time. No one has disturbed their encampment. Each time as they wait they add a few improvements. They wait. More arrive. More. What a host, what a host! What a forest in the seed! The whole of the air above them and below them flocks to their camp begging to be allowed to be their banners. The sounds of the glass smithies ring day and night. The stars laugh in anticipation.

And the earth, being of that celestial ancestry, remembers this season before its creatures do. Now if you mark their places day by day you will see that stones weighing many tons have begun to move across level fields, carving deep grooves in the outcroppings, and you may be able to hear their voices-muffled 
rumblings and shriekings, so that you remember tales of caverns full of beards at the end of which spirits without age slept with their crowns on the tables. The roots of the trees feel a stirring and the leaves tremble on still days.

And now when you open the door at night you will see huge animals leap away into the darkness. You will think at first that they are running from you. The eland is gone in a single bound, the white of his eye flashing like a comet. The cave bear breaks away like an ice jam on a black river. The mammoth moves as though stung, a black haystack, a night sweeping across the sky. In silence. But they will not have seen you. You are no more to them than a writing on a wall. How long will you haunt the earth together?

The catastrophe they are running from never ceases but moves through the universe, recurring in its own time, whereupon the days of glass in their millions all fall together and remain, centuries of them, in a single solid sheet many fathoms deep. The animals' flight, then, is no more than a kind of cyclic worship, a dance before the event. It may consecrate them but it can never save them. The glass days fall to the earth suddenly on a spring morning when the mammoth's mouth is full of daisies.

And what of you? Do the animals run to your right or to your left? With the motion of the earth or against it? And have you saved your skins one after the other to offer to the translucent god? Have you invoked his protection each time a knife blade touched a stone, each time a glass rang? God of bells. Do you still have your little obsidian key which will allow you to enter, barefoot, the grating corridors, to pass naked by the vast halls where the animals stand like clouds, to forget each in turn, to ease your bones and your anguish through the grinding doors at last and into the head of the glass valley and hear your first bird sing, and kill the creature which does not yet know you, and laugh at the first touch of feathers, and warm your hands around its heart, and eat? 